\title{
Financing Education and Socioeconomic Inequality in Mexico: New Educational Challenges
}

\author{
Vicente Llorent-Bedmar ${ }^{1}$, Teresa Terrón-Caro ${ }^{2} \&$ Mercedes Llorent-Vaquero $^{3}$ \\ ${ }^{1}$ Faculty of Sciences of Education, University of Seville, Seville, Spain \\ ${ }^{2}$ Faculty of Social Sciences, University of Pablo de Olavide, Seville, Spain \\ ${ }^{3}$ Faculty of Sciences of Education, University of Seville, Seville, Spain \\ Correspondence: Vicente Llorent-Bedmar, Dpto. de Teoría e Historia de la Educación. Fac. de CC. de la \\ Educación, Calle Pirotecnia s/n, 41013 Sevilla, Spain. Tel: 349-5542-0559. E-mail: 1lorent@us.es
}

Received: July 16, 2014 Accepted: August 27, 2014 Online Published: August 28, 2014

doi:10.5539/res.v6n3p130 URL: http://dx.doi.org/10.5539/res.v6n3p130

\begin{abstract}
Notwithstanding the progress that has been made over the past decade, the challenges currently facing the Mexican education system must be tackled without delay. A preliminary step to developing appropriate strategies to compensate for the uneven results obtained by students as a result of socioeconomic and cultural factors was to analyze the relationship between the funding of education and equity in Mexico, as well as discern new challenges to be faced in this area in order to eliminate social inequialities and improve the quality of education. We collected information via participant observation and documentary analysis, using materials such as UNESCO's Second Comparative and Explanatory Regional Study, and the Instituto Nacional para la Evaluación de la Educación de México [National Institute for the Evaluation of Education in Mexico] in order to further our knowledge of this complex area of study. The results we obtained confirm that formal education in Mexico in no way guarantees effective equality of opportunity, nor does it reduce the social inequalities stemming from socioeconomic context and family background; on the contrary it reproduces, multiplies and even intensifies the differences that exist before the pupil has even entered the school system.
\end{abstract}

Keywords: education and development, educational finance, educational quality and social inequality

\section{Introduction}

Boosting a country's educational performance is, without doubt, a highly complicated task and even education systems with a successful track record face important challenges in teaching standards, especially in the state sector. Naturally, the most difficult challenges are those faced by countries with the least favorable socioeconomic conditions. There is no question that objective results in education and social development will be achieved in the long term and after a good deal of hard work. However, this hard work is rewarded, in this sense, in the words of John W. Meyer (2010, p. 25): "Education restructures whole populations, creating and expanding elites and redefining rights and obligations of members".

International comparative studies and research focusing on education systems (for example, the OECD's Program for International Student Assessment, better known as PISA) declare that the development of human capital is closely linked to the productivity, economic progress and, of course, social welfare of a country (OCDE, 2010). Furthermore, studies of very different kinds have concluded by stating that a high performing school model has an impact on the growth of GDP (Guisán, 2009; Guisán \& Neira, 2001; Hanushek \& Woessmann, 2007). Education plays an undeniably important role in the development and progress of citizens and the societies in which they live.

By the same token, it is clear that countries with a high GDP, such as Finland, Canada, Australia and Belgium, traditionally obtain very good results in the PISA report. However, PISA 2009 (OECD, 2010) showed that the correlation is not constant, since countries like China and Korea, with GDPs lower than the OECD average, obtained - alongside Finland - the best results in school performance.

These facts lead us to believe that if a country makes the right choices in its global strategies and the implementation of its educational policy —independently of how economically developed the country is - it may 
be inferred that their school systems are successful. This is an assertion with undoubted repercussions for the human and economic capital of countries that are growing.

The effect that education can have on a society, as a mechanism that generates human capital, has meant that today the principal motivation underpinning human capital theory has been extended from simply accounting for wage differentials between individuals to that of explaining economic growth (Willis, 1986). Indeed, according to Dickson \& Harmond (2011, p. 1120), we can argue that "economics has perhaps been somewhat 'underpowered' in terms of research that recognises how education can define major life outcomes - occupation marriage/relationships and so on - but also can change you as a person - increasing your sense of self esteem, self awareness and consideration of the future".

Based on these premises, our research focus is Mexico, which currently faces a significant challenge in pursuit of social and economic progress: to reinforce its education system by improving both its quality and equity (OCDE, 2010). Successfully meeting the challenge would imply making significant and comprehensive improvements such as, providing teaching staff with training to upgrade their work, strengthening the system of managing and financing schools and establishing a system for assessing quality, through which proposals for progress could be made to each teacher regarding, among other things, their own practices.

With regards to this matter, we should take note of the Mexican government. First, the Political Constitution of the Mexican United States of 1917 includes the right to education, the pursuit of increasing schooling rates and the duty of the State to ensure a quality education (Órgano del Gobierno Provisional de la República Mexicana, 1917). More recently, we found the mission of the Ministry of Public Education, which decrees, again, the right to access to quality education for all Mexicans. Also, the function of this organization is based on values such as equality, commitment, respect and honesty, among others (Secretary of Public Education of Mexico, 2013).

\section{Method}

The terms of reference for this study are the social sciences. More specifically, we opted to use documentary and field research to describe, analyze, and interpret the subject matter in order to gain a better understanding of its complex nature. The tools used for data collection were documentary analysis as well as participant observation, the results of which were then used to provide answers to our research objectives, which are set out below:

- To describe and analyze the existing relationship between the funding of education and equity in Mexico, as well as discern new challenges to be faced in this area in order to eliminate social inequalities and improve the quality of education.

- To examine the effects of education on the social and economic development of Mexico, both now and in future years.

- To describe and analyze the relationship between the demographic bonus and the educational challenges involved in governing Mexico.

- To study the relationship between educational inequality arising from the segregated schooling variable - segregated, that is, by socioeconomic and cultural conditions - and differences in academic performance in the present-day education system in Mexico.

The series of questions that underpinned our research and guided our study were the following: What is the socioeducational profile of the population of Mexico? How does demographic change influence the country's development? What are the main challenges facing the education system in Mexico? What are the repercussions of socioeconomically-segregated schooling on academic results? Are there major disparities between rural and urban environments, or between federal entities as far as the learning outcomes of pupils are concerned? What new challenges face the Mexican government in eliminating socioeducational inequalities?

The observation has been understood as a process where an interaction is made, a participative relationship between the observer and the context being studied. As indicated by Alessandro Duranti (2000), at all times, it has been tried to keep a balance between passive and complete participation, depending on the response considered the most accurate for each case. Through the observation it has been obtained information about the environment that surrounds the families and the contexts studied, especially focusing on the socioeconomic inequalities in some states and in rural and urban areas. Undoubtedly, this process has encouraged a better understanding of the information obtained through documentary analysis. The instrument employed for the collection of information was the observation record, developed by the principal investigators of the study. 


\section{Results}

\subsection{First and Second Objectives: Financing Education and Educational Equity}

As we outlined in the introduction, the development of human capital is closely linked in every country with productivity, economic progress and, of course, social welfare. Investing in education, therefore, is a major key to progress in Mexican society, and is demonstrated in the comprehensive scope of the development strategies that are currently being planned. To take an example, we could cite the project Metas educativas 2021: la educación que queremos para la generación de los Bicentenarios, Educational goals for 2021: the education we want for the Bicentenary generation, whose objectives are "to improve quality and equity in education in order to combat poverty and inequality, and so favour social inclusion" (Organización de Estados Iberoamericanos para la Educación, la Ciencia y la Cultura (OEI), 2010, p. 9).

The right kind of investment in education is essential for Mexicans to adapt to technological and demographic change, as and when it occurs. In 2006, Mexico spent 5.7\% of its GDP on education, on a par with the OECD average; in 2008, Mexico's education expenditure increased to $6.27 \%$ of its GDP, of which $4.69 \%$ corresponded to public sector investment in education made at national, federal entity and local levels, as well as $1.32 \%$ made by private individuals.

As can be seen, national expenditure on education is similar to, and even higher than that of countries that have education systems of better quality, such as Austria, the Czech Republic, Germany, and others (INEE, 2009). Even so, we should bear in mind that spending more on education does not necessarily imply that there is an improvement in its quality, but that this expense must be distributed effectively, and this is one of the inescapable challenges that Mexico has to face (OCDE, 2010).

If every Mexican is to receive a basic education, as stipulated in the constitution, it is necessary to work out a suitable formula for financing it, to favour the equitable development of education throughout the country and redress the current imbalances between the various federal entities that arose when education was decentralized in 1992. In fact, the main problem of the present system (approved in 2007) stems from the criterion that was established by the Fondo de Aportaciones para la Educación Básica y Normal (FAEB), Fund for Contributions to Compulsory Basic Education, for allocating state education expenditure to the various federal entities, since it "does not take into account the size of the entities or the magnitude of its educational obligation" (Mancera, 2010, p. 167); as a result of this criterion, the largest entities were penalized. At present, an alternative is being considered: to allocate national education expenditure according to the effort made by each federal entity. Likewise, since the central government is aware of the geographical, social and economic diversity existing in Mexico, it should play a countervailing role in order to achieve genuine equity in education irrespective of where it takes place. According to the estimates made by Mancera, there is a significant difference in the expenditure required - more than double, in fact - to educate a student in a small locality, compared to what is needed for one in a city centre school (Mancera, 2010). In the same vein, another criterion being considered for the proper distribution of national education expenditure concerns the financial resources of each federal entity.

In the following section we can observe how factors of a socioeconomic and cultural nature, among other things, have a considerable influence on student performance; all the more reason for creating the conditions necessary to favour or compensate for the limitations of certain marginal areas of the country in offering its students a quality education that is also equitable, as we were able to verify from our observations on the ground. We understand, in line with Mancera (2010), that in addition to the equitable allocation of funds for state education between the various federal entities, compensatory measures should be taken to redress the weaknesses of particular schools in obvious conditions of inequality.

\subsection{Third Objective: Demographic Factors and Academic Performance}

Mexico is currently undergoing a process of demographic transition; from 1970 to the present day the rate of population growth has slowed from 3\% to $0.77 \%$ (Consejo Nacional de Población, 2010). If we look at the population pyramid on January 1, 2011 (graph 1), we can see that the two subgroups that include adolescents and young adults predominate over all the others; more specifically, citizens between 15 and 24 years old form 18.6\% of the population in 2011. This is a significant figure in the context of making education policy decisions. 


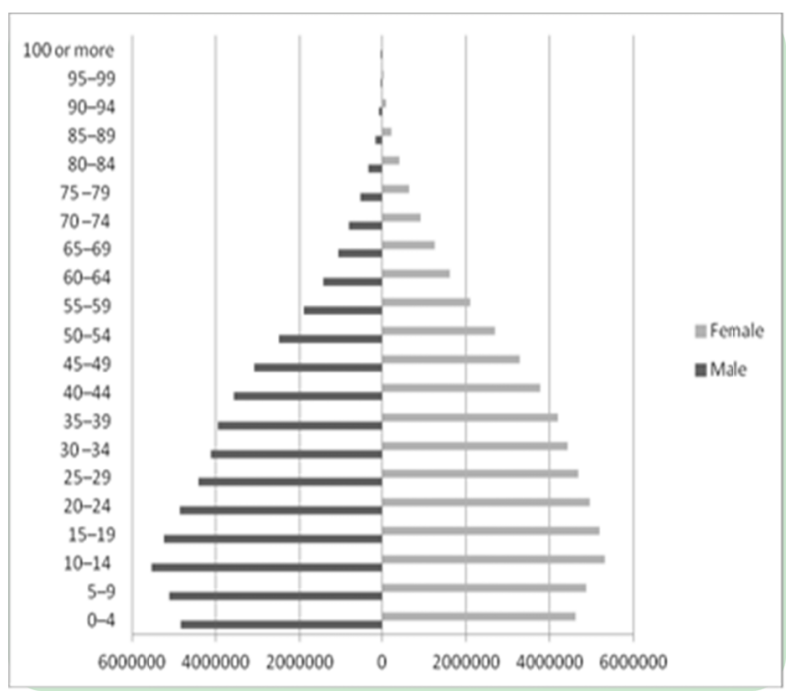

Figure 1. Population of the Republic of Mexico, January 1, 2011

Source: Prepared by the authors using data supplied by CONAPO

This new scenario has had a great impact on the dependency ratio of the population (Note 1), since Mexicans of working age are now beginning to outnumber those who are not. This could be very beneficial since, by taking advantage of the phenomenon known as the "demographic bonus", or "window of demographic opportunity", it will be possible to boost the country's economic growth in the coming decades. It is estimated that, between 2000 and 2030, seven hundred and thirty thousand people a year on average will enter the workforce, a situation which ought to be reflected in the creation of new jobs - and, of course, in an improvement in the quality of these - and in a more highly skilled and productive workforce (Consejo Nacional de Población, 2008). These demographic changes have fostered advances in preventive medicine and family planning, migration, and the population policy carried out by the National Population Council (Consejo Nacional de Población, 2010).

Despite this, and even though the situation just described augurs well for future economic growth in Mexico, it also means that the government will have to negotiate this demographic process by taking certain actions and implementing strategies that respond to social needs at all times. This is made clear in the Programa Nacional de Población 2008-2012. Por un cambio demográfico a favor del desarrollo, National Population Program 20082012: Towards a demographic change favoring development. This instrument sets out the population policy to be adopted in order to resolve the key challenges they presently face, which are: a. to invest in the human capital of young people; b. to create quality jobs; c. to increase levels of income and savings; and d. to adapt social and economic institutions accordingly (Consejo Nacional de Población, 2008).

A clear priority for the Mexican authorities, as well as an objective in the short and medium-term, is therefore to educate young people and train them as human capital so that they can enter the labor market under the best possible conditions. For this reason, the importance given to improving the quality of high school education (1517 years old) and higher education (18-24 years old) should come as no surprise, and the document referring to the comprehensive reform of high school education (EMS) in Mexico expressly states:

“(...) competitiveness in Mexico depends in large measure on developing this educational level in an appropriate way. The coverage and quality of the EMS represent fundamental assumptions for the country to provide a response to the challenges of a global economy within an equitable framework." (Subsecretaría de Educación Media Superior de México, 2008, p. 4)

The Mexican education system has made progress in the last ten years: compulsory pre-primary school education for 3 to 5 year olds was progressively introduced between 2004/2005 and 2008/2009; there has been a constant increase in investment in education; school enrolment between 5 and 14 years is practically universal; various programs focusing on improving education - the Program for Quality Schools, the Program for Full Time Schools, the Emerging Program for the Improvement of Educational Attainment-have been introduced. Nonetheless, the national government still needs to strengthen basic education (OCDE, 2010). From 2005 to the present day, the Mexican population between the ages of 3 and 14 (Basic Education) has dropped considerably and will continue to do so in the coming years. This makes it easy to improve the quality of educational and 
social services for this segment of the population. With less demand, efforts must be directed towards improving the services offered (Instituto Nacional para la Evaluación de la Educación (INEE), 2009). Bearing in mind the social and demographic conditioning factors, Mexican society faces pressing educational challenges, which we think should be addressed without delay:

a. Reduce the drop-out rate at each educational level. To obtain a quality education system requires - in addition to meeting a series of indicators - that a free basic education should be available to all children, and that they should not drop out of school during this stage.

As can be seen in the following graph, the national drop-out rate has gradually fallen over the years. In $2000 / 2001$, the percentage of pupils who abandoned their studies in primary school (6-11 years old) stood at $1.9 \%$, a figure which had fallen to $1.1 \%$ in the $2007 / 2008$ school year. At secondary level (12-14 years old), the drop-out rate of $8.30 \%$ also decreased considerably after $2000 / 2001$, to $6.8 \%$ in $2007 / 2008$, even though this figure continues to give cause for concern.

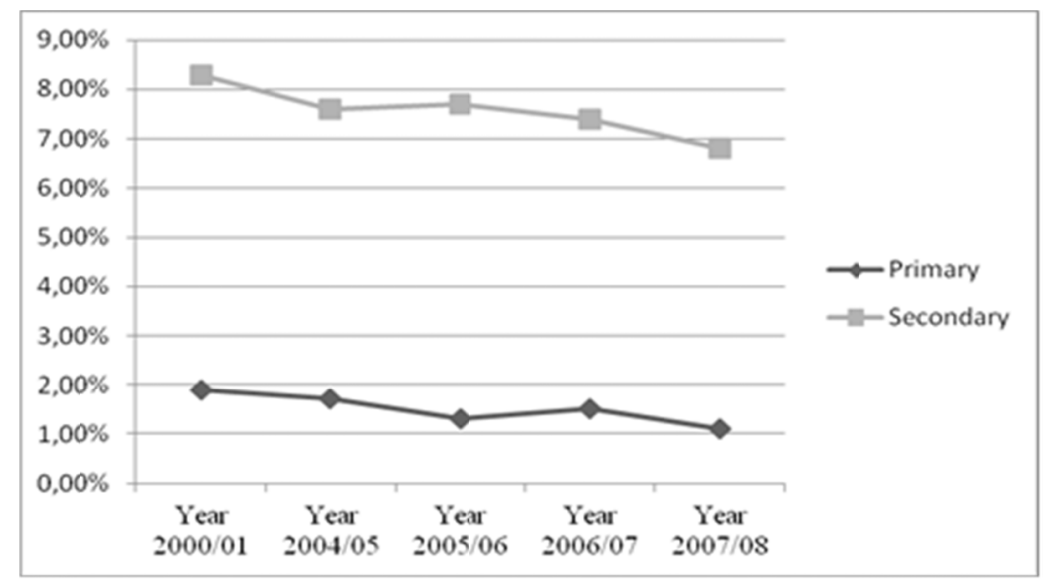

Figure 2. Total school drop-out rate by level of study

Source: Prepared by the authors on the basis of data from the Instituto Nacional para la Evaluación de la Educación, INEE, 2005, 2006, 2007 and 2009

b. $\quad$ Promote teaching at the higher levels of education, giving priority to meeting the needs of the labor market. This kind of teaching should favor the development of skills and knowledge, without neglecting the formation of values and attitudes that favor the active participation of school leavers as citizens of their communities. As we have said, Mexico's ability to compete in a global economy and its social development depend in large measure on the coverage and quality of high school education (Secretaría de Educación Pública de México, 2008).

c. Improve the quality of education. Improving the professionalization and profile of teachers, as well as the approaches and teaching methods employed, should be among the criteria for enhancing the quality of education, as well as updating schools, installations and equipment (Secretaría de Educación Pública, 2007).

d. Reduce social inequality and optimize educational achievement in schools. As we shall see in the following section, one of the great challenges that the Mexican system faces is promoting equitable treatment among all children and young people, irrespective of socioeconomic, ethnic or cultural background, gender, or the region where they live, any of which can be a source of educational disadvantage and outcome (Secretaría de Educación Pública, 2007). Successfully dealing with these issues will help ensure equality of opportunity for everyone.

\subsection{Fourth Objective: Socioeconomic Factors and Academic Performance}

In line with the conclusions expressed in the Second Regional Comparative and Explanatory Study (SERCE), undertaken by UNESCO in 2008, we are of the opinion that the Latin American group of countries suffers the greatest social inequalities in the world. As a consequence, this is reflected in the unequal results that pupils obtain, both regionally and in each of the separate member countries (Murillo \& Román, 2009).

Furthermore, formal education in Mexico does not guarantee genuine equality of opportunity at all, nor does it reduce the social inequality deriving from family background and socioeconomic context; on the contrary, it 
ends up reproducing, multiplying and even intensifying existing differences even before entry into the school system. For this reason, we see an analysis of existing social inequalities as a necessary prerequisite to planning the strategic reinforcements needed to compensate for them. The SERCE study revealed that socioeconomic and cultural factors have a considerable impact on pupil performance. Segregation in schooling as a result of socioeconomic and cultural factors is rated as the variable with the second highest specific impact, along with other variables, such as school environment (the most important variable) and school resources overall (UNESCO, 2008a, pp. 44-45).

If we examine the percentage of the school-age population in compulsory basic education with high or very high levels of marginalization because of the area where they live (Note 2), we can see that there are big differences between some federal entities and a particularly significant difference between the rural and urban areas (see graphs 3 and 4).

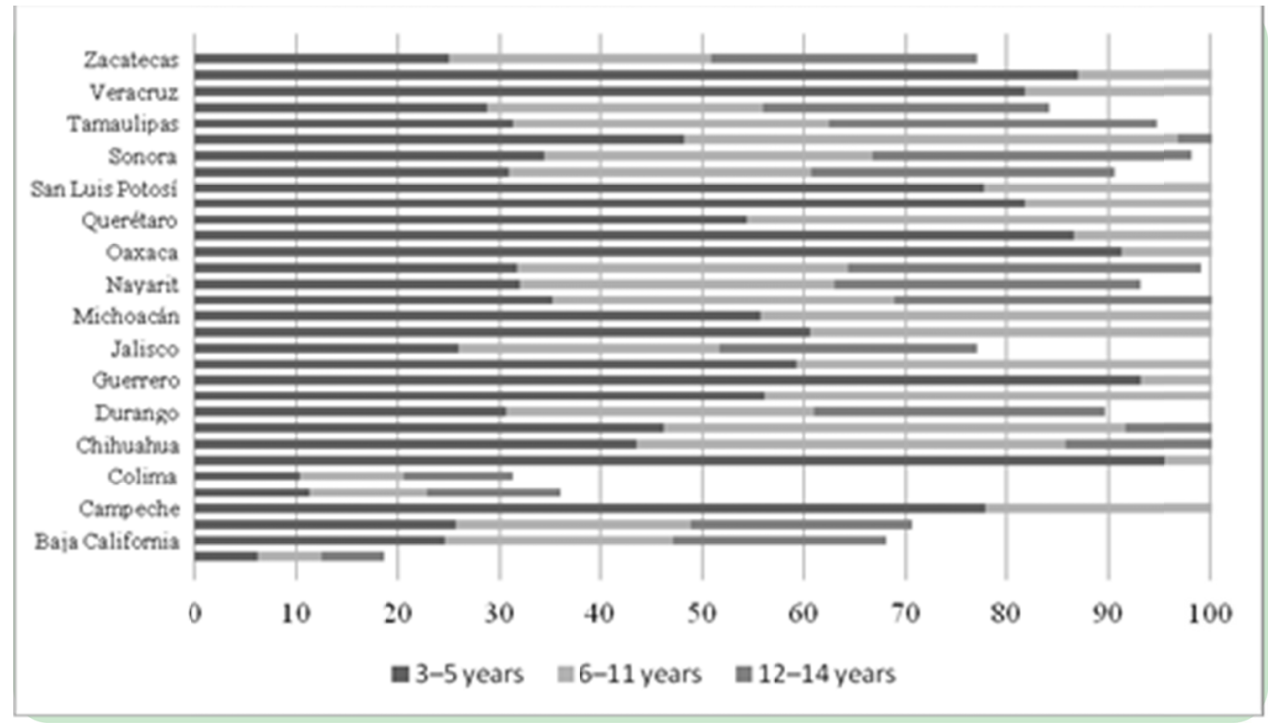

Figure 3. Percentage of scholl-age population in compulsory basic education living in conditions of high and very high marginalization. Rural areas, 2005

Source: Compiled by the authors using data from the INEE, 2009

Of the total number of pupils between 3 and 14 years old who live in rural areas of Mexico, two thirds (66.1\%) live in conditions of high or very high marginalization. The highest percentages of marginalized students are concentrated in the federal entities of Chiapas (95.3\%), Guerrero (93.1\%), Oaxaca (91.7\%), Puebla (86.9\%), Yucatán (86.5\%), Quintana Roo (82.6\%), Veracruz (81.7\%), San Luis Potosí (78\%) and Campeche (78.8\%), with Aguascalientes (6.2\%), Colina (10.4\%) and Coahuila (11.9\%) at the opposite end of the scale (INEE, 2009, pp. 67-69).

On the other hand, in urban areas, 32.4\% of all pupils between 3 and 14 years old live in conditions of high or very high marginalization. We can see, therefore, that there is a considerable percentage difference overall between students in rural and urban areas. The indicator showed that students in rural areas suffer greater vulnerability than those in urban areas and this was verified through information gathered from observations made during the field study.

The noticeable disparity between the urban and rural environments in Latin America and the Caribbean arising from an inequitable socioeconomic and cultural situation extends to the differential academic performances of the students and segregated schooling (Note 3). According to the results of the SERCE study, Mexico is, along with Peru and Brazil, one of the countries with the greatest disparity between the urban and rural environments. Only in Nicaragua and Paraguay is there no significant association between the location of the school and academic performance (UNESCO, 2008a).

Not surprisingly, the academic results obtained by pupils in urban schools were better than those of pupils enrolled in rural schools, irrespective of subject area or level of study. Below we show percentage results for Mexico at the four levels of performance devised for use in the SERCE study. According to SERCE, the 
complexity of knowledge in each subject area increases in line with level of performance. Murillo and Román (2009) explain that the ideal distribution would be for most pupils to be concentrated in levels III and IV.

Table 1. The relationship between performance levels attained by pupils (\%) in rural and urban schools in Mexico, by grade and subject area

\begin{tabular}{lllllllllll}
\hline & \multicolumn{4}{c}{ Urban area (\%) } & \multicolumn{4}{c}{ Rural area (\%) } \\
\cline { 2 - 11 } & \multicolumn{1}{c}{ I } & II & III & IV & $<$ I & I & II & III & IV \\
\hline Grade 3, Primary Mathematics & 3.67 & 26.14 & 29.95 & 21.58 & 18.66 & 8.95 & 35.84 & 32.61 & 14.91 & 7.69 \\
Grade 6, Primary Mathematics & 0.36 & 6.41 & 29 & 48.89 & 23.33 & 0.92 & 3.70 & 41.6 & 34.26 & 9.52 \\
Grade 3, Primary Reading & 2.06 & 14.89 & 36.43 & 31.16 & 15.47 & 7.76 & 31.83 & 38.80 & 18.18 & 3.43 \\
Grade 6, Primary Reading & 0.15 & 8.87 & 29.60 & 32.38 & 29.01 & 0.45 & 21.27 & 43.67 & 22.68 & 11.93 \\
\hline
\end{tabular}

Source: Data from SERCE study, UNESCO, 2008b, pp. 196-198

As the table above shows, the percentages of pupils achieving the best levels of performance (III and IV, in bold) are clearly higher in the urban areas than in the rural. $40.24 \%$ of urban pupils in Grade 3 Primary Mathematics achieved scores in the two highest bands, compared to $22.6 \%$ of those from rural areas; the corresponding figures in Grade 6 Primary Mathematics for urban and rural pupils were $72.22 \%$ and $43.78 \%$, respectively. In Reading, the figures for urban and rural pupils for Grade 3 Primary were $46.63 \%$ and $21.61 \%$, respectively, and $61.39 \%$ and $34.61 \%$ for Grade 6 Primary, respectively. These data also show us that in urban and rural environments alike, the higher the level of study, the better the results. However, it is evident that there is an urgent need to draw up and implement education policies that will alleviate the enormous differences between the urban and rural environments in as short a time as possible (Murillo \& Román, 2009).

If we examine the degree of marginalization in the federal entities, we observe that there are significant differences here as well. The territories of Oaxaca (76.1\%), Chiapas (73.6\%), Guerrero (70.51\%), Puebla (64.7\%) and Tlaxcala $(61.0 \%)$ are grouped at one end of the scale with the highest percentages of very marginalized pupils. Our observations during field work confirmed this information. On the other hand, Aguascalientes and Nuevo León, with $2.3 \%$ and $6.1 \%$, respectively, have the lowest percentages of high marginalization (INEE, 2009).

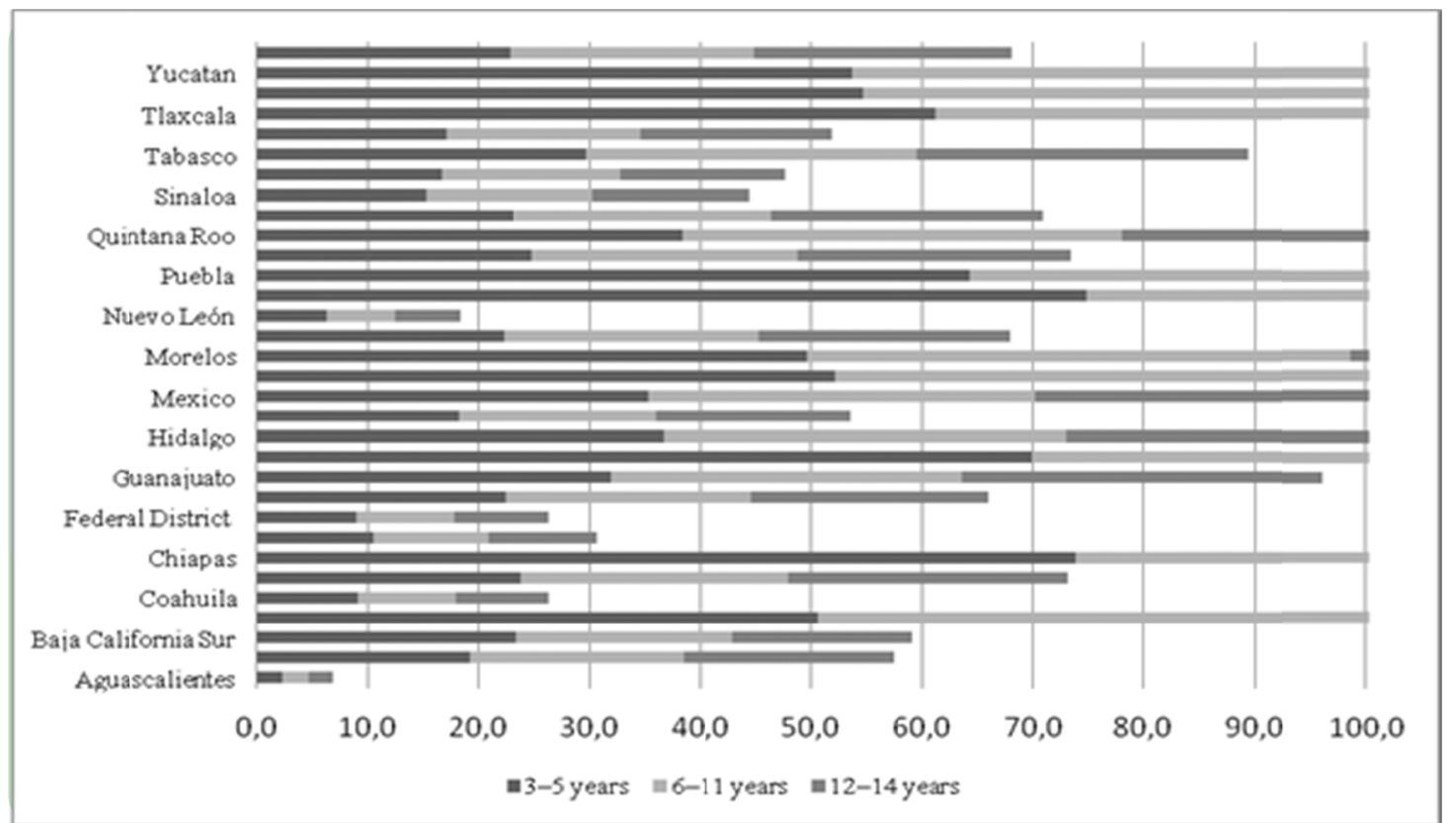

Figure 4. Percentage of regulation school age population in basic education living in marginal or very marginal conditions. Urban areas, 2005

Source: Compiled by the authors, using data from the INEE, 2009 
Concerning the extremes of educational performance (unsatisfactory and advanced) obtained by Grade 3 Secondary level students in the different federal entities in Spanish and Mathematics, as reported by the INEE (2009, pp. 229-245), our attention will focus specifically on the percentage of pupils in 2005 and 2008 with significant weaknesses in knowledge, skills or abilities at this curricular level, that is, with an unsatisfactory level of performance. We shall also comment on the percentage of students in the same grade who attained an advanced standard in knowledge, skills and abilities.

Table 2. Percentage of pupils with unsatisfactory educational achievement in 2005 and 2008, Spanish and Mathematics, Grade 3 Secondary

\begin{tabular}{|c|c|c|c|c|c|c|}
\hline & & Spa & $(\%)$ & & Matl & $(\%)$ \\
\hline & & 2005 & 2008 & & 2005 & 2008 \\
\hline & Chiapas & 51.2 & 48.4 & Chiapas & 62.8 & 64.4 \\
\hline & Guerrero & 44.4 & 47 & Guerrero & 61.6 & 67.7 \\
\hline & Oaxaca & 46.1 & 45.3 & Tabasco & 61.6 & 67.3 \\
\hline$\stackrel{B}{B}$ & Nayarit & 37.9 & 45.8 & Oaxaca & 59.1 & 57.4 \\
\hline$\overline{\mathbf{E}}$ & Aguascalientes & 33.1 & 33.5 & Nuevo León & 52.8 & 49.4 \\
\hline$\overline{7}$ & Nuevo León & 32.7 & 31.8 & Aguascalientes & 45.5 & 45.0 \\
\hline$\frac{5}{0}$ & Federal District & 17.9 & 25.6 & Federal District & 39.8 & 38.8 \\
\hline (x) & National & 32.7 & 35.9 & National & 51.1 & 51.9 \\
\hline
\end{tabular}

Source: Compiled by the authors with data from the INEE, 2009, p. 234

As can be seen from the table above, in 2005 and 2008 the federal entities of Chiapas, Guerrero and Oaxaca had the highest percentages of students with an unsatisfactory standard of Spanish. In Mathematics, Chiapas, Guerrero and Oaxaca, along with Tabasco, stand out yet again. We may, therefore state that some of the federal entities with the highest concentrations of seriously and very seriously marginalized students of school age in compulsory basic education-namely, Chiapas, Guerrero and Oaxaca-also have the highest percentages of students in Grade 3 of Secondary Education with an unsatisfactory standard of educational achievement.

On the other hand, we were unable to confirm an expected relationship between federal entities with a lower incidence of marginalized and highly marginalized students (of school age and in compulsory basic education) and lower percentages of unsatisfactory educational achievement. To demonstrate this, Aguascalientes and Nuevo León were the federal entities with the least incidence of extreme marginalization and, if the relationship held, they would also have the smallest percentage of students with unsatisfactory educational attainment. However, if we look at Table 2 above, we see that it is the Federal District that stands out, in both 2005 and 2008 , as having the lowest percentage of students with deficient standards in Spanish and Mathematics.

An important point is that of the 32 federal entities in Mexico, only 13 remained, in both 2005 and 2008, below the average percentages of unsatisfactory educational attainment at national level in Spanish; in Mathematics, the figure fell even more, with just 9 of them in the same situation. Another point to be brought out is that the national average for Spanish for the indicator analyzed (unsatisfactory standard) increased significantly from $32.7 \%$ in 2005 to $35.9 \%$ in 2008 (see Table 2) instead of progressively falling in order to approach an ideal distribution: fewer students of an unsatisfactory educational standard, more students attaining an advanced level of achievement.

As mentioned above, we now turn to consider the percentages of students by federal entity at Grade 3 Secondary level who achieved an advanced standard in knowledge, skills and abilities. This time, the trend is not as clearly marked as in the previous case; Oaxaca, Chiapas and Guerrero continued to have lower percentages of pupils than the national average obtaining advanced standards, although other federal entities were in a similar position. It must on the other hand be pointed out that there were significant differences between the percentages of pupils with advanced standards in Spanish and Mathematics, with the higher values being obtained in Spanish. The national averages illustrate this: Spanish: $5.3 \%$ in $2005,6.1 \%$ in 2008 ; Mathematics: $1.4 \%$ in $2005,2.1 \%$ in 2008.

The Federal District, however, did maintain its position as the entity with the best results in Spanish and Mathematics during the years studied. Generally speaking, the federal entities in the table below increased or maintained the number of its students achieving an advanced standard in Spanish between 2005 and 2008. Only in Nayarit did the figure go down, from $2.9 \%$ in 2005 to $2.1 \%$ in 2008 . This trend, however, was not maintained 
in Mathematics in all federal entities; those with percentages above the national average in 2005 showed improvements in their results in 2008, whereas those with percentages below the national average in 2005 tended to show worse results in 2008, except for Oaxaca, where they improved.

Table 3. Percentage of students attaining an advanced educational standard in Spanish and Mathematics in 2005 and 2008 , Grade 3 Secondary

\begin{tabular}{|c|c|c|c|c|c|c|}
\hline & & Spar & (\%) & & Math & $(\%)$ \\
\hline & & 2005 & 2008 & & 2005 & 2008 \\
\hline & Federal District & 11.7 & 12 & Federal District & 2.9 & 4.4 \\
\hline & Querétaro & 6.7 & 9.9 & Aguascalientes & 2.1 & 3.5 \\
\hline & Colima & 6 & 8.1 & Sinaloa & 2.1 & 3.5 \\
\hline$\stackrel{B}{E}$ & Tamaulipas & 5.4 & 7.5 & Durango & 1.5 & 3.4 \\
\hline = & Aguascalientes & 6.4 & 6.7 & $\ldots$ & $\ldots$ & $\ldots$ \\
\hline ส & $\ldots$ & $\ldots$ & $\ldots$ & Oaxaca & 0.6 & 1 \\
\hline 림 & Oaxaca & 1.7 & 3.8 & Chiapas & 0.7 & 0.6 \\
\hline & Zacatecas & 2.4 & 3.6 & Zacatecas & 1.1 & 0.5 \\
\hline & Chiapas & 2.3 & 2.5 & Guerrero & 0.6 & 0.4 \\
\hline & Guerrero & 2.5 & 2.5 & Michoacán & 0.7 & 0.4 \\
\hline & Nayarit & 2.9 & 2.1 & Tabasco & 0.5 & 0.2 \\
\hline & National & 5.3 & 6.1 & National & 1.4 & 2.1 \\
\hline
\end{tabular}

Source: Compiled by the authors using data from the INEE, 2009, p. 242

\section{Discussion}

In view of the preceding analysis, and using the research objectives presented at the beginning of the study as a reference point, the following are our capitals considerations:

With respect to the first and second objectives:

- In recent years, Mexico's investment in education as a percentage of GDP has been practically on a par with the OECD average. At the same time, the quality of its results still leaves a good deal to be desired, particularly those relating to equity between students, irrespective of where they live in the country.

- Mexico needs a new financial formula for allocating national educational expenditure better between the different federal entities, one which will eliminate existing imbalances.

- The federal government should play a countervailing role so that true educational equity exists, irrespective of where the education takes place.

With respect to the third objective:

- The process of demographic transition in Mexico may have some effect on improving the country's economic growth in the coming decades, as long as the government invests in the development of its human capital, particularly the young. One of the short and medium-term challenges that most concerns the Mexican authorities is to improve the quality of education for students in High Schools (15-17 years) and Higher Education (18-24 years). This would be the best investment for developing the human capital that must enter the labor market under the best possible conditions.

- We consider that the pressing educational challenges that Mexican society must address without delay are, according to the Secretaría de Educación Pública de México (2008): a. To reduce the school drop-out rate; $b$. To promote teaching at the higher educational levels, giving priority to its relevance and making it commensurate with the needs of the labor market; $\mathrm{c}$. To improve the quality of education; d. To reduce social inequalities and optimize educational achievement in schools.

With respect to the fourth objective:

- There is a great difference between the rural and urban environments with regard to the numbers of students who live in marginal and very marginal conditions: rural students are significantly more vulnerable. 
- Irrespective of the subject area or educational level evaluated, we have confirmed that the academic results of students in urban schools are better than those who attend rural schools.

- Factors of a socioeconomic and cultural nature have a considerable bearing on student performance. In fact, we were able to confirm that particular federal entities with high and very high levels of marginalization have, in turn, higher proportions of their student population with unsatisfactory educational standards.

\section{Conclusion and Final Considerations}

As a conclusion, this research raises the need of further deepening in the study of the causes of the existing inequalities arising from socioeconomic and cultural deficits in Mexican education. A quality and equitable education system must be able to precisely eliminate the differences in educational performance which have been shown in this paper next to their factors and reasons. In this sense, one of the lines of research derived from the present study is trying to shed light on to what extent it is the performance of the whole school community (teachers, family and students) one of the main factors that are causing the impossibility of guaranteeing an effective equality of opportunities in formal education. Also, another line of research would be investigating those other good practices that are being carried out to reduce current social inequalities. The results of the studies in this line will be of particular importance to attain improvements in the educational system of Mexico.

\section{References}

Consejo Nacional de Población (CONAPO). (2008). Programa Nacional de Población 2008-2012. Por un cambio demográfico a favor del desarrollo. Gobierno Federal, Hamburgo. Retrieved June 20, 2014, from http://www.conapo.gob.mx/pnp/PNP_2008_2012.pdf

Consejo Nacional de Población (CONAPO). (2010). Primer informe de ejecución del Programa Nacional de Población 2008-2012. Por un cambio demográfico a favor del desarrollo. Gobierno Federal, Hamburgo: Retrieved June 28, 2014, from http://www.conapo.gob.mx/publicaciones/informes/primero/Doc _completo.pdf

Dickson, M., \& Harmond, C. (2011). Economic returns to education: What We Know, What We Don't Know, and Where We Are Going - Some brief pointers. Economics of Education Review, 30, 1118-1122. http://dx.doi.org/10.1016/j.econedurev.2011.08.003

Duranti, A. (2000). Antropología Linsgüistica. Madrid: Cambridge.

Guisán, Ma . C. (2009). Educación, calidad del gobierno y desarrollo económico en América, Europa, África y Asia. Estudios Económicos de Desarrollo Internacional, 9(2), 5-24.

Guisán, Mª C., \& Neira, I. (2001). Educación y crecimiento: una perspectiva mundial, 1960-1999. Estudios Económicos de Desarrollo Internacional, 1(1), 9-29.

Hanushek, E., \& Woessmann, L (2007). The role of education quality for economic growth. Policy Research, Study report WPS 4122. The World Bank, Washington, DC. Retrieved June 24, 2014, from http://www-wds.worldbank.org/external/default/WDSContentServer/WDSP/IB/2007/01/29/000016406_20 070129113447/Rendered/PDF/wps4122.pdf

Instituto Nacional para la Evaluación de la Educación (INEE). (2009). Panorama educativo de México 2009. Banco de Indicadores Educativos [online]. Retrieved July 1, 2014, from http://www.inee.edu.mx/index.php /bases-de-datos/banco-de-indicadores-educativos

Instituto Nacional para la Evaluación de la Educación (INEE). (2005). Panorama educativo de México 2005. Banco de Indicadores Educativos [online]. Retrieved June 26, 2014, from http://www.inee.edu.mx /bie_wr/mapa_indica/2005/PanoramaEducativoDeMexico/AT/AT14/2005_AT14_.pdf

Instituto Nacional para la Evaluación de la Educación (INEE). (2006). Panorama educativo de México 2006. Banco de Indicadores Educativos [online]. Retrieved July 2, 2014, from http://www.inee.edu.mx/bie _wr/mapa_indica/2006/PanoramaEducativoDeMexico/AT/AT16/2006_AT16_.pdf

Instituto Nacional para la Evaluación de la Educación (INEE). (2007). Panorama educativo de México 2007. Banco de Indicadores Educativos [online]. Retrieved from June 28, 2014, http://www.inee.edu.mx /bie_wr/mapa_indica/2007/PanoramaEducativoDeMexico/AT/AT08/2007_AT08_.pdf

Instituto Nacional para la Evaluación de la Educación (INEE). (2008). Panorama educativo de México 2008. Banco de Indicadores Educativos [online]. Retrieved June 24, 2014, from http://www.inee.edu.mx/bie_wr /mapa_indica/2008/PanoramaEducativoDeMexico/AT/AT08/2008_AT08_.pdf 
Mancera, C. (2010). Financiamiento de la educación básica. In A. Arnaut, \& S. Giorguli, Los grandes problemas de México. (Vol. VII, pp. 159-183). El Colegio de México: Mexico DF.

Meyer, J. W. (2010). Los efectos de la educación como institución. In J. W. Meyer, \& F. Ramírez (Eds.), La educación en la sociedad mundial.Octaedro (pp. 25-53). ICE: Barcelona.

Murillo, F. J., \& Román, M. (2009). Mejorar el desempeño de los estudiantes de América Latina. Algunas reflexiones a partir de los resultados del SERCE. Revista mexicana de investigación educativa, 14(41), 451-484.

OCDE. (2010). Mejorar las escuelas: Estrategias para la acción en México. OECD Publishing. http://dx.doi.org /10.1787/9789264087682-es

OECD. (2010). PISA 2009 Results: Learning to Learn - Student Engagement, Strategies and Practices (Vol. III). http://dx.doi.org/10.1787/9789264083943-en

Organización de Estados Iberoamericanos para la Educación, la Ciencia y la Cultura (OEI). (2010). Metas educativas 2021. La educación que queremos para la generación de los bicentenarios. Final document. Síntesis: Madrid.

Órgano del Gobierno Provisional de la República Mexicana. (1917). Constitución Politica de los Estados Unidos Mexicanos. Diario Oficial de la Federación 5 de febrero de 1917. Retrieved August 12, 2014, from http://www.diputados.gob.mx/LeyesBiblio/htm/1.htm

Secretaría de Educación Pública de México. (2008). Reforma integral de la educación media superior en México: La creación de un sistema nacional de bachillerato en un marco de diversidad. Retrieved June 25, 2014, from http://www.profordems.cfie.ipn.mx/profordems3ra/modulos/mod1/pdf/modulo1/Sistema_Nacional _Bachillerato.pdf

Secretaria de Educación Pública de México. (2013). Visión y misión de la SEP. Retrieved August 14, 2014, from http://www.sep.gob.mx/es/sep1/sep1_Vision_de_la_SEP\#.U-3Vavl_sko

Secretaría de Educación Pública. (2007). Programa sectorial de educación 2007-2012. México. Retrieved June 26, 2014, from http://upepe.sep.gob.mx/prog_sec.pdf

Subsecretaría de Educación Media Superior de México. (2008). Reforma integral de la educación media superior en México: La creación de un sistema nacional de bachillerato en un marco de diversidad. Retrieved June 28, 2014, from http://www.profordems.cfie.ipn.mx/profordems3ra/modulos/mod1/pdf /modulo1/Sistema_Nacional_Bachillerato.pdf

UNESCO. (2008a). Los aprendizajes de los estudiantes de América Lanita y el Caribe. Resumen Ejecutivo SERCE. Laboratorio Latinoamericano de Evaluación de la Calidad de la Educación. UNESCO: Chile. Retrieved June 22, 2014, from http://mt.educarchile.cl/MT/jjbrunner/archives/libros/Serce_08/Serce resejec.pdf

UNESCO. (2008b). Los aprendizajes de los estudiantes de América Lanita y el Caribe. Primer Reporte SERCE. Laboratorio Latinoamericano de Evaluación de la Calidad de la Educación. UNESCO: Chile. Retrieved June 21, 2014, from http://diniece.me.gov.ar/images/stories/diniece/evaluacion_educativa/internacionales /SERCE\%202006.\%20Los\%20aprendizajes\%20de\%20los\%20estudiantes\%20de\%20America\%20Latina\% 20y\%20el\%20Caribe.pdf

Willis R. J. (1986) Wage determinants: a survey and reinterpretation of human capital earning functions. In O. Ashenfelter, \& R. Layard (Eds.), Handbook of Labour Economics (Vol. 1 pp. 525-602). Retrieved August 10, 2014, from http://www.sciencedirect.com/science/handbooks/15734463/1

\section{Notes}

Note 1. According to the Consejo Nacional de Población [National Population Council], the dependency ratio is "The proportion represented by the sum of the populations of less than 15 years old and of 60 or more, as compared to the population between 15 and 59 years old." Retrieved from http://www.conapo.gob.mx /index.php?option $=$ com_content $\&$ view $=$ article $\&$ id $=220 \&$ Itemid $=342$

Note 2. The indicator defined by the Instituto Nacional para la Evaluación de la Educación as: “... the number of people of an age to pursue studies at any of the levels of basic education (3-5 pre-primary, 6-11 primary, and 12-14 secondary), who live in districts with high or very high marginalization typified as urban or locality level 
marginalization; for every 100 people in the total population in the same age group and according to the type of place of residence" (INEE, 2009, 66).

Note 3. Urban-rural inequity as a function of the variable segregation of schooling for socio-economic or cultural reasons also affects the academic performance of students in Latin America and the Caribbean.

\section{Copyrights}

Copyright for this article is retained by the author(s), with first publication rights granted to the journal.

This is an open-access article distributed under the terms and conditions of the Creative Commons Attribution license (http://creativecommons.org/licenses/by/3.0/). 